\title{
EVALUASI PENGARUH COUNTRY-OF-ORIGIN, MEREK, DAN HARGA PADA PEMBELIAN PRODUK SUSU IMPORT
}

\author{
W Mahestu Noviandra Krisjanti \\ Universitas Atma Jaya Yogyakarta
}

\begin{abstract}
Indonesian people tend to prefer and have a good perception about imported products compare to the domestic products. Indeed, when they don't have any competence to judge the quality of the product they will use country-of-origin, brand and also the price as a basic. Therefore, this research will evaluate those three variables in imported product buying decision, in the case of imported infant milk. The research will analyze whether mother as the decision maker of this product is influenced by country-of-origin, brand and price.

From the data analysis, it is found that only price and brand which influence the buying decision. Country-of-origin doesn't influence the buying decision significantly.
\end{abstract}

Keywords: country-of-origin, harga, merek, susu bayi import

\section{PENDAHULUAN}

Salah satu efek dari pasar terbuka adalah masuknya merek-merek asing ke Indonesia. Ada beberapa strategi yang biasa digunakan oleh produsen asing untuk memasukkan produknya ke negara lain, termasuk Indonesia. Strategi yang paling rendah resikonya adalah eksport produk ke pasar negara lain. Strategi lain adalah lewat pemberian ijin produiksi dengan merek tertentu di pasar negara lain. Strategi ini dikenal dengan nama lisensi. Resiko atas lisensi relatif kecil karena investasi di pasar negara yang dimasuki tidak dilakukan oleh pemilik merek tersebut. Modal ventura juga menjadi pilihan beberapa produsen asing untuk memasukkan produknya ke pasar luar negri. Strategi masuk dengan komitmen tertinggi dikenal dengan nama Foreign Direct Investment atau investasi secara langsung di pasar luar negri. Lewat strategi ini produsen asing menginvestasikan modalnya secara langsung di pasar yang akan dimasuki. Atau dengan kata lain, mereka memproduksi di pasar negara yang dimasuki.

Merek asing yang masuk ke pasar Indonesia meliputi banyak industri. Bisa dikatakan bahwa dalam hampir semua industri yang ada di Indonesia, ada pemasin asing di dalamnya walaupun mereka terlibat secara tidak langsung. Salah satu industri yang diserbu merek asing adalah industri susu formula untuk segmen pasar anakanak. Pada saat ini banyak produk susu untuk anak-anak yang bisa ditemui di pasar. Mulai dari produk susu buatan Indonesia dengan nama merek Indonesia, buatan Indonesia dengan nama merek asing dan juga produk susu buatan produsen asing yang di hasilkan di luar negri. Produk yang disebut terakhir ini masuk ke Indonesia dengan strategi eksport.

Pada umumnya pengambil keputusan pemilihan maupun pembelian untuk produk susu anak-anak terutama untuk segmen pasar susu anak bawah lima tahun adalah orang tua mereka, dan secara spesifik ibu mereka. Tidak sedikit para ibu yang memilih produk susu buatan luar negri dengan berbagai pertimbangan. Ada banyak variabel yang mempengaruhi keputusan evaluasi produk yang pada akhirnya nanti pada keputusan pembelian produk susu. Menurut Ahmed, Johnson dan Boon (2002), evaluasi produk luar negri itu paling tidak dipengaruhi oleh 3 variabel yaitu harga, merek dan country-of-origin. 


\section{Evaluasi Pengaruh Country-of-origin, Merek, dan Harga Pada Pembelian Produk Susu Import \\ (W Mahestu Noviandra Krisjanti)}

Dalam penelitian ini akan diuji, apakah country-of-origin memberikan pengaruh yang signifikan pada keputusan pembelian produk susu buatan luar negri. Lebih jauh akan diuji apakah country-of-origin memberikan pengaruh yang lebih besar pada evaluasi produk dibanding dua variabel indepen lainnya yaitu merek dan harga.

\section{TINJAUAN LITERATUR}

\subsection{Country of Origin}

Beberapa penulis mempunyai pemahaman yang kurang lebih sama terhadap definisi country-of-origin, seperti misalnya Badri, Davis dan Davis (1995) memahami efek country-of-origin sebagai efek "made in". Sedangkan Ahmed, Johnson dan Boon (2004) secara jelas mendefinisikan country-of-origin sebagai "country of manufacture or assembly that is identified by "made in" or manufactured in" labels. Czinkota dan Ronkainen (2001) bahkan menyebutkan bahwa country-of-origin dipahami sebagai efek yang muncul dalam persepsi konsumen yang dipengaruhi oleh lokasi dimana suatu produk dihasilkan. Lokasi atau negara tempat suatu produk dihasilkan akan mempengaruhi persepsi orang mengenai kualitas produk tersebut. Semakin banyak informasi yang dimiliki oleh konsumen, maka efek country-of-origin akan semakin berkurang. Hal ini disebabkan oleh terbentuknya rasionalitas konsumen akan kualitas suatu produk. Hal senada disampaikan oleh Zhang (1996) yang mengatakan bahwa ketersediaan informasi yang jelas dan dapat dipercaya akan mendorong sikap tertentu pada pemilihan produk.

Dalam beberapa penelitian (Ahmed dan d"Astous: 2004; Kaynak dan Kara, 2002; Kaynak, Kucukemiroglu dan Hyder, 2000) disepakati bahwa konsumen mempunyai persepsi tertentu mengenai lokasi/negara tempat suatu produk dihasilkan. Ketika konsumen hanya mempunyai informasi lokasi suatu produk dihasilkan, maka dalam pengambilaan keputusan pembelian akan dipengaruhi oleh persepsi konsumen akan negara tersebut.

Dengan masuknya produk-produk asing ke suatu negara dengan strategi modal ventura, investasi secara langsung maupun lisensi sebagai salah satu efek dari pasar terbuka maka semakin berkurang juga produk-produk buatan luar negri. Namun demikian beberapa tahun terakhir terdapat aktivitas efisiensi di beberapa perusahaan, seperti $P$ \& $G$, dengan menutup pabrik di beberapa negara dan mensentralkan di satu negara saja. Usaha ini ternyata bisa memberikan kontribusi penurunan biaya produksi yang cukup signifikan. Dan tentu saja di beberapa negara mucul efek country-of-origin yang mempengaruhi persepsi konsumen terdapat kualitas produk tersebut.

\subsubsection{Pendekatan dalam Riset Country-of-Origin}

Menurut Kaynak, Kucukemiroglu dan Hyder (2000), Terdapat empat pendekatan dalam riset mengenai country-of-origin. Keempat pendekatan tersebut adalah, single cue studies, multi-cue studies, conjoint analysis dan environmental analysis.

Pada pendekatan yang pertama, dalam melakukan evaluasi produk konsumen menggunakan dasar baik intrinsik maupun ekstrinsik. Seperti misalnya penggunaan country-of-origin sebagai single cue dalam riset mengenai produk anggur atau rokok. Konsumen memandang produk-produk tersebut sangat erat dengan negara tertentu, misalnya produk anggur dari perancis. Pada pendekatan yang kedua, selain country-of-origin digunakan sebagai faktor dalam evaluasi produk, terdapat faktor-faktor lain yang diteliti seperti misalnya harga, merek dan sebagainya.

Diyakini bahwa dua pendekatan tersebut masih mempunyai kelemahan, maka didesainlah pendekatan ketiga untuk mengakomodasi kelemahan dua pendekatan terdahulu. Pada conjoint analysis ini peneliti dimungkinkan untuk mengukur seberapa besar nilai konsumen terhadap atribut-atribut produk. Secara lebih jelas, peneliti bisa melihat alasan dibalik keputusan konsumen dalam memilih produk asing versus produk domestik.

Pada pendekatan terakhir, environmental analysis, faktor-faktor lingkungan dimasukkan. Studi tentang faktorfaktor lingkungan terkait dengan kondisi sosio ekonomi dan teknologi negara suplier. Perlu dipahami bagaimana berbagai faktor lingkungan akan mempengarhui persepsi konsumen mengenai produk dan merek asing maupun domestik. 


\subsubsection{Pengaruh Country-of-Origin Terhadap Ekuitas Merek}

Telah diketahui bahwa lokasi dimana produk dihasilkan (made-in effect) akan mempengaruhi niat beli maupun keputusan pembelian oleh konsumen. Suatu negara akan dipersepsikan mempunyai reputasi yang eksklusif atas suatu produk tertentu. Namun demikian country-of-origin bukanlah satu-satunya penentu keputusan pembelian oleh konsumen. Menurut Lin dan Kao (2004), country-of-origin akan menciptakan suatu persepsi tertentu akan suatu merek/ produk, dimana persepsi bisa positif maupun negatif. Pada pada level berikutnya persepsi positif akan mendorong terciptanya pembelian aktual.

Pada saat ini semakin banyak produk yang menekankan informasi lokasi produksi terutama produk-produk yang berasal dari negara maju. Dimana negara maju dipersepsikan mempunyai korelasi yang positif dengan kualitas produk. Salah satu produk yang mengangkat informasi "made-in" adalah oli Top 1 yang selalu mengedepankan informasi "dibuat di Amerika". Hal ini didukung dengan aktifitas promosi terutama iklan yang dilakukan oleh Top 1 yang mengekspos lokasi pembuatan produk tersebut dengan model iklan Dewa.

Pada saat ini semakin banyak produk yang menekankan informasi lokasi produksi terutama produk-produk yang berasal dari negara maju. Dimana negara maju dipersepsikan mempunyai korelasi yang positif dengan kualitas produk. Salah satu produk yang mengangkat informasi "made-in" adalah oli Top 1 yang selalu mengedepankan informasi "dibuat di Amerika". Hal ini didukung dengan aktifitas promosi terutama iklan yang dilakukan oleh Top 1 yang mengekspos lokasi pembuatan produk tersebut dengan model iklan Dewa.

\subsection{Merek}

Aaker (1997) mendefinisikan merek sebagai suatu nama dan/ atau simbol yang bersifat membedakan dengan maksud mengidentifikasi barang atau jasa dari seorang penjual atau sekelompok penjual tertentu, dengan demikian membedakannya dari barang-barang dan jasa yang dihasilkan oleh pesaing.

Keberadaan merek akan memudahkan konsumen dalam mencari produk yang dikehendaki di pasar. Namun demikian yang sering terjadi adalah diferensiasi produk antara satu merek dengan merek yang lain tidak terlalu signifikan sehingga muncul perilaku perpindahan merek yang disebabkan oleh beberapa variabel misalnya promosi, kualitas produk yang dipersepsikan, citra produk, kemasan dan label, harga dan sebagainya.

Merek mempunyai beberapa peran terutama dalam area pemasaran. Beberapa diantaranya adalah memberi tanda pada konsumen mengenai sumber produk tersebut dan melindungi konsumen maupun produsen dari para kompetitor yang berusaha memberikan produk-produk yang identik (Aaker, 1997). Kotler (2004) secara lebih spesifik menjelaskan peran merek terutama dalam aktivitas pemasaran, seperti misalnya identifikasi produk, informasi tentang kualitas, jaminan fitur yang sama, proteksi keunikan dan lebih jauh lagi komtribusi merek pada aktivitas segmentasi pasar.

\subsubsection{Ekuitas Merek}

Ekuitas merek adalah seperangkat aset dan liabilitas merek yang berkaitan dengan suatu merek, nama dan simbolnya, yang menambah atau mengurangi nilai yang diberikan oleh sebuah barang atau jasa kepada perusahaan atau para apelanggan perusahaan (Aaker, 1997). Yang menjadi dasar dalam ekuitas merek adalah loyalitas merek, kesadaran nama, kesan kualitas, asosiasi merek sebagai tambahan terhadap kesan kualitas dan aset-aset merek lain seperti misalnya paten dan cap.

Walaupun ekuitas merek sulit untuk diukur namun ekuitas merek tersebut merepresentasikan nilai suatu merek pada organisasi. Ekuitas kerek yang tinggi akan memberikan keunggulan bersaing bagi suatu merek atau produk. Beberapa diantaranya adalah (Kotler, 2004) memberikan harga, kualitas dan posisi menawar yang lebih tinggi pada produsen. Lebih jauh lagi ekuitas mereka akan memungkinkan perusahaan dapat dengan mudah melakukan strategi ekstensi merek karena dalam merek tersebut terdapat kredibilitas yang tinggi

Variabel merek sebagai salah satu variabel yang dipertimbangkan oleh konsumen dalam melakukan evaluasi produk. Untuk produk yang dihasilkan di negara lain, ketika konsumen tidak banyak mendapat informasi tentang country-of-origin, maka mereka akan berusaha menlakukan judgemen kualitas berdasakan merek. Menurut 


\section{Evaluasi Pengaruh Country-of-origin, Merek, dan Harga Pada Pembelian Produk Susu Import \\ (W Mahestu Noviandra Krisjanti)}

Szybillo dan Jacoby (1974) dalam Ahmed, Johnson dan Boon (2004), kemapanan suatu merek akan dikaitkan dengan tingkat kualitas produk tersebut.

\subsubsection{Loyalitas Merek}

Menurut Schiffman dan Kanuk (1994), loyalitas merek merupakan suatu pilihan yang konsisten atau pembelian merek yang sama yang dilakukan oleh konsumen atas suatu produk tertentu. Loyalitas merek menurpakan satu ukuran keterkaitan seorang pelanggan pada sebuah merek (Aaker, 1997). Sedangkan Ferrel (2002) memahami loyalitas merek sebaga suatu perilaku positif terhadap suatu merek yang mendorong konsumen untuk secara konsisten membeli merek tersebut ketika mereka membutuhkan kategori produk tersebut. Ketiga definisi tersebut mencerminkan bagaimana seorang pelanggan mungkin tidak akan beralih ke merek lain jika merek tersebut membuat suatu perubahan, baik dalam harga atau dalam unsur-unsur produk.

Pada tingkat paling dasar pembeli tidak loyal sama sekali dengan merek sehingga dalam keputusan pembelian, merek memainkan peran yang sangat kecil. Pada tahap berikutnya, pembeli yang tidak mengalami ketidakpuasan tidak mendapat stimulasi untuk berpindah merek terutama jika perpindahan tersebut membutuhkan usaha. Berikutnya, adalah orang-orang yang puas sehingga untuk menarik kelompok ini, kompetitor harus bisa mengatasi biaya peralihan dengan memberikan tawaran yang memberikan manfaat cukup besar. Pada tahap keempat, orang-orang telah sungguh-sungguh menyukai suatu merek. Preferensi mereka terhadap suatu merek sangat tinggi. Kelompok yang terakhir adalah pelanggan yang setia. Mereka mempunyai kebanggaan dengan menjadi pengguna suatu merek tertentu.

Dari semua hal mengenai merek yang dilakukan oleh perusahaan ada satu aktivitas yang sering lupa dilakukan oleh para pemasar yaitu menjaga dan mempertahankan mere. Dalam bayak hal, pemasar melupakan merawat merek ketika merek mereka sudah mulai mapan di pasar. Kadang terjadi arogansi bahwa merek mereka adalah yang paling populer menjadi bumerang baik para pemasar tersebut. Yang harus dilakukan oleh pemasar adalah mengkomunikasikan posisi merek secara kontinyu kepada konsumen. Komunikasi tersebut bisa menggunakan berbagai strategi salah satunya adalah periklanan. Dengan aktivitas komunikasi tersebut pemasar secara tidak langsung juga membangun preferensi merek dan loyalitas merek. Tentu saja maintenance merek tidak cukup dilakukan lewat periklanan saja terjadi yang tidak kalah pentingnya adalah lewat pengalaman konsumen akan merek tersebut. Selain itu untuk membangun dan mempertahankan loyalitas konsumen akan suatu merek perlu juga dilakukan interaksi antara produsen dan konsumen baik lewat telepon, internet maupun sarana yang lainnya.

\subsection{Harga}

Secara umum, harga bisa didefinisikan sebagai sejumlah uang yang harus dikorbankan oleh konsumen untuk mendapatkan suatu produk atau jasa. Harga bisa menjadi daya tarik atau penentu dalam pengambilan keputusan pembelian. Namun demikian harga juga bisa menjadi hambata atau barrier dalam keputusan pembelian. Pengambilan keputusan yang kurang tepat dalam pricing akan menyebabkan turunnya minat beli konsumen pada produk tersebut.

Pada saat tertentu, konsumen akan menilai kualitas produk berdasarkan tingkat harganya jika mereka hanya mempunyai informasi yang terbatas mengenai produk tersebut. Semakin tinggi harga suatu produk, maka semakin tinggi pula kualitas produk tersebut. Namun demikian jika konsumen menilai suautu produk tidak terlalu tinggi, maka mereka enggan membeli produk tersebut jika harga yang ditetapkan tinggi.

Dalam aktivitas pemasaran yang melewati batas suatu negara, ada beberapa faktor lingkungan yang mempengaruhi keputusan tingkat harga suatu produk. Faktor-faktor tersebut adalah (Keegan, 2004):

a. fluktuasi mata uang

b. nilai tukar uang

c. tingkat inflasi

d. subsidi dan pengendalian dari pemerintah 
$\begin{array}{ll}\text { e. } & \text { perilaku persaingan } \\ \text { f. } & \text { relasi antara harga dan kualitas }\end{array}$

\subsection{Keputusan Pembelian}

Konsep pemasaran merekomendasikan kepada para pemasar untuk memberikan kepuasan kepada konsumennya. Untuk dapat memuaskan mereka, perusahaan harus mampu memenuhi kebutuhan dan keinginan konsumen tersebut. Termasuk di dalamnya motif yang mendasari mengapa seseorang membeli suatu produk, dimana mereka membeli kapan mereka membeli, berapa yang mereka beli, pada tingkat harga berapa mereka mau membeli produk tersebut. Perilaku konsumen tersebut dipengaruhi oleh dua variabel penting yaitu karakateristik pembeli dan proses pengambilan keputusan pembelian.

Diawali dengan tahap mencari atau mengenali kebutuhan, konsumen akan beranjak pada tahap kedua yaitu pencarian inofrmasi. Informasi yang mereka cari seputar produk, merek dan juga produsen produk tersebut. Informasi-informasi yang terkumpul akan dievaluasi pada tahap berikutnya. Sebagai output dari tahap ketiga adalah keputusan pembelian. Ketika telah melakukan pembelian dan mengkonsumsi produk yang dibeli, mereka akan mengevaluasi baik produk maupun pelayanan yang mereka terima dalam proses pembelian. Hasil evaluasi yang positif akan mendorong mereka untuk melakukan pembelian ulang di masa yang akan datang. Namun evaluasi yang negatif akan memotivasi mereka untuk tidak lagi mengkonsumsi produk tersebut.

\section{METODA PENELITIAN}

\subsection{Definisi Operasional Variabel Penelitian}

1. Variabel Demografi

Variabel demografik yang dibutuhkan dalam penelitian ini adalah tingkat pengeluaran keluarga dan usia. Selain itu juga akan dihimpun informasi mengenai status responden terkait dengan perilaku pembelian produk susu anak-anak buatan luar negri. Secara umum data ini akan digunakan untuk mengetahui profil kelompok konsumen sebagai subyek penelitian ini.

2. Variabel Harga

Variabel harga dalam penelitian ini adalah tingkat harga yang akan menjadi pertimbangan konsumen dalam melakukan evaluasi produk.

3. Variabel Country-of-origin

Dalam penelitian ini yang termasuk dalam variabel country-of-origin adalah rasa/ aroma, prestise dan kualitas yang diasosiaikan dengan makanan yang dalam riset ini adalah susu anak-anak. Item dari variabel tersebut diambil dari pendapat Roth dan Romeo (1992).

4. Variabel Merek

Dari beberapa penelitian terdahulu diketahui bahwa merek akan menjadi variabel yang mempengaruhi pilihan produk ketika informasi tentang country-of-origin tidak banyak didapat. Menurut Ettenson dan Gaeth (1991) loyalitas merek merupakan salah satu bukti bahwa merek yang mapan ternyata menjadi variabel penting dalam evaluasi produk.

5. Niat beli

Yang dimaksud dengan niat beli dalam penelitian ini adalah preferensi pada produk tertentu dibandingkan produk yang lain, membeli produk pada saat membutuhkan, tidak membeli produk yang lain ketika produk tertentu tidak ada di pasaran.

\subsection{Bentuk Penelitian}

Penelitian ini merupakan penelitian deskriptif, yaitu penelitian yang bertujuan memberikan pemahaman dan pengertian secara mendalam terhadap suatu objek dengan memformulasikan suatu masalah secara lebih tepat. Penelitian semacam ini untuk menentukan alternatif tindakan yang akan dilakukan sehingga mendapatkan 
gambaran yang jelas mengenai suatu permasalahan. Subyek penelitian ini adalah wanita yang anaknya mengkonsumsi produk susu buatan luar negri.

\subsection{Penentuan Sampel dan Pengumpulan Data}

Metode survai merupakan metode pengumpulan data primer melalui komunikasi tertulis dengan responden sebagai sampel individual yang representatif. Survai dilakukan untuk mendapatkan informasi yang diperlukan secara cepat, tidak mahal, efisien dan akurat (Sekaran, 1992).

Responden penelitian ini diambil dengan metode sampel purposive sampling, yaitu sampel yang ditentukan berdasarkan pada ciri tertentu yang dianggap mempunyai hubungan erat dengan ciri populasi (Hadi, 2001). Responden yang diambil dalam penelitian ini adalah wanita yang anaknya mengkonsumsi produk susu buatan luar negri dimana wanita (ibu) tersebut memainkan peran sebagai pengambil keputusan pembelian produk tersebut.

\subsection{Validitas dan Reliabilitas Instrumen Penelitian}

Pada tahap awal penelitian perlu dilakukan pengujian validitas dan reliabilitas terhadap instrumen penelitian. Validitas adalah taraf sejauh mana ketepatan dan kecermatan suatu alat ukur dalam melakukan fungsi ukurnya. Suatu instrumen memiliki validitas tinggi jika dapat memberikan hasil ukur yang sesuai dengan maksud dilakukannya pengukuran tersebut. Pengujian validitas ini dapat menggunakan teknik korelasi Product-Moment Pearson. Berikut adalah hasil olah data yang menunjukkan bahwa semua item pertanyaan valid sehingga bisa digunakan dalam penelitian ini.

Tabel1.

Pengujian Validitas Kuesioner

\begin{tabular}{|c|c|c|c|c|}
\hline No & Variabel & Item & $\begin{array}{c}\text { Corected Item-Total } \\
\text { Correlation }\end{array}$ & Kesimpulan \\
\hline \multirow{4}{*}{1} & \multirow{4}{*}{ Niat beli } & N1 & .6780 & Valid \\
\hline & & N2 & .7745 & Valid \\
\hline & & N3 & .8755 & Valid \\
\hline & & N4 & .5417 & Valid \\
\hline \multirow{4}{*}{2} & \multirow{4}{*}{ Harga } & $\mathrm{H} 1$ & .7442 & Valid \\
\hline & & $\mathrm{H} 2$ & .8305 & Valid \\
\hline & & $\mathrm{H} 3$ & .9351 & Valid \\
\hline & & $\mathrm{H} 4$ & .8587 & Valid \\
\hline \multirow{5}{*}{3} & \multirow{5}{*}{ Country-of-Origin } & C1 & .8407 & Valid \\
\hline & & $\mathrm{C} 2$ & .9702 & Valid \\
\hline & & C3 & .9578 & Valid \\
\hline & & C4 & .9455 & Valid \\
\hline & & C5 & .8821 & Valid \\
\hline \multirow{5}{*}{4} & \multirow{5}{*}{ Merek } & M1 & .8270 & Valid \\
\hline & & M2 & .8295 & Valid \\
\hline & & M3 & .8894 & Valid \\
\hline & & M4 & .9015 & Valid \\
\hline & & M5 & .7802 & Valid \\
\hline
\end{tabular}

Sumber : hasil pengujian validitas

Reliabilitas juga diukur dengan menggunakan koefisien cronbach alpha. Instrumen penelitian disebut handal bila pengujian tersebut menunjukkan alpha lebih dari 0,7 (Sekaran, 1992). Hasil olah data menunjukkan bahwa semua nuilai alpha berada diatas 0,7 sehingga bisa dikatakan reliabel. 
Tabel 2.

Pengujian Reliabilitas Kuesioner

\begin{tabular}{|c|c|c|c|}
\hline No & Variabel & Alpha & Kesimpulan \\
\hline 1 & Niat Beli & .8485 & Reliabel \\
\hline 2 & Harga & .9243 & Reliabel \\
\hline 3 & Country-of-origin & .9705 & Reliabel \\
\hline 4 & Merek & .9399 & Reliabel \\
\hline
\end{tabular}

Sumber : hasil pengujian reliabilitas

Dengan demikian semua item pertanyaan dalam kuesioner dianggap valid dan reliabel untuk riset ini.

\section{PEMBAHASAN}

\subsection{Hasil Respon Kuesioner}

Pengumpulan data penelitian dilakukan dengan cara menyebarkan 330 kuesioner secara langsung kepada responden penelitian. Kuesioner yang dikembalikan responden sebesar 273 eksemplar (response rate $83 \%$ ), dimana hanya 212 kuesioner yang layak untuk dianalisis. Sedangkan yang lainnya dinyatakan tidak valid untuk dilanjutkan dalam pengolahan data karena tidak memenuhi syarat pengisian. Responden yang disyaratkan adalah ibu yang anaknya mengkonsumsi susu import. Namun demikian, ada banyak responden yang tidak mengetahui bahwa susu yang dikonsumsi adalah buatan dalam negri (domestic product). Mereka berasumsi bahwa produkproduk susu dengan merek tertentu adalah produk buatan luar negri.

\subsection{Profil Responden Konsumen}

Berdasarkan usia responden, responden dengan kelompok usia 30-40 tahun berada pada persentase tertinggi, diikuti dengan kelompok usia 21-30 tahun. Sedangkan kelompok usia dibawah 21 tahun hanya berjunlah 3 orang saja. Informasi ini bisa dipahami dengan penjelasan bahwa pada saat ini orang cenderung menikah di usia mendekati 30 tahun. Sehingga responden dengan anak balita pasti akan cenderung banyak di kelompok ini. Hasil lengkapnya dapat dilihat pada tabel berikut ini.

Tabel 4.1.

\section{Frekuensi Responden Berdasarkan Usia}

\begin{tabular}{ccc}
\hline & Frequency & Percent \\
\hline$<=20$ tahun & 3 & 1.4 \\
$\$ 0$ tahun & 81 & 38.2 \\
30-40 tahun & 87 & 41.0 \\
$>40$ tahun & 41 & 19.3 \\
\hline Total & 212 & 100.0 \\
\hline Sumber $:$ hasil estimasi frekuensi &
\end{tabular}

Sedangkan profil responden berdasarkan pengeluaran keluarga dapat dilihat pada tabel 4.2. Kelompok responden tertinggi ada pada kelompok keluarga dengan tingkat pengeluaran sebesar Rp. 2.000.000,- sampai Rp. 4.000.000,-. Tingkat pengeluaran ini bisa dikelompokkan pada keluarga menengah keatas. Kelompok ini juga yang biasanya membeli produk susu impor untuk anak-anaknya. Kelompok dengan tingkat pengeluaran diatas Rp. $4.000 .000,0$ hanya kurang dari 30\%. Hal ini bisa dijelaskan bahwa responden yang disasar adalah keluarga muda, dimana tingkat pengahasilan keluarga belum semapan keluarga dengan usia perkawinan lebih dari 10 tahun. Oleh karena itu tingkat pengeluaran keluargapun tidak akan terlalu tinggi pada kelompok ini. 
Tabel 3.

Frekuensi Responden Berdasarkan Tingkat Pengeluaran Keluarga

\begin{tabular}{ccc}
\hline & Frequency & Percent \\
\hline$<$ Rp 2.000.000 & 24 & 11.3 \\
Rp. 2 juta - Rp 4 juta & 125 & 59.0 \\
$>$ Rp 4.000.000 & 63 & 29.7 \\
\hline Total & 212 & 100.0 \\
\hline
\end{tabular}

Sumber : hasil estimasi frekuensi

\subsection{Pengaruh Harga, Country-of-Origin dan Merek terhadap Niat Beli Konsumen}

Tabel 4.3. menunjukkan hasil olahan regresi dengan variabel terikat niat beli dan variabel bebas harga, country-of-origin dan merek.

Tabel 4.

Hasil Regresi Niat Beli

\begin{tabular}{ccc}
\hline & Beta & Sig, \\
\hline (Constant) & & .009 \\
HARGA & .707 & .000 \\
COO & .030 & .566 \\
MEREK & .199 & .001 \\
\hline Sumber : hasil estimasi regresi &
\end{tabular}

Sumber : hasil estimasi regresi

Dengan menganalisis koefisien beta dan level signifikansi pada setiap variabel bebas, kemampuan prediktif masing-masing variabel bebas terhadap niat beli bisa diuji. Dari hasil pengujian individu menggunakan uji t terhadap koefisien regresi harga dan merek diketahui bahwa dua variabel ini mempunyai pengaruh yang signifikan pada niat beli pada level signifikansi 1\%. Sedangkan koefisien regresi untuk variabel country-of-origin menunjukkan bahwa variabel ini tidak memberikan pengaruh yang signifikan pada niat beli.

Dilihat dari koefesien regresi, maka variabel hargalah yang mempunyai nilai beta tertinggi. Hal ini menunjukkan bahwa dari ketiga variabel bebas, variabel harga akan memberikan pengaruh yang paling besar pada variabel niat beli produk susu import. Sangat bisa dipahami bahwa variabel harga akan memberikan pengaruh yang paling besar pada variebel niat beli karena secara umum bisa diduga bahwa orang tua bagaimanapun juga akan sensitif pada tingkat harga. Apalagi dengan tingkat pengeluaran keluarga yang tidak bisa dikatakan sangat tinggi, maka harga pasti akan menjadi faktor penentu dalam pengambilan keputusan pembelian.

Dari data usia responden yang didominasi kelompok 2-40 tahun bisa pula dikaitkan dengan koefisien regresi tersebut. Kelompok usia tersebut belum bisa dikatakan sebagai kelompok usia yang sudah memasuki masa ekonomi keluarga mapan, maka dalam pembelian produk, harga akan sangat dipertimbangkan.

Namun demikian, variabel merek tidak bisa dipandang sebelah mata. Terlebih dengan karakter konsumen Indonesia yang cenderung berorientasi pada produk-produk impor. Merek yang berasosiasi dengan "western" atau negara maju akan mempengaruhi niat beli konsumen. Maka tidaklah heran jika banyak produk yang menggunakan nama yang berasosiasi dengan "western". Lebih lanjut bisa dijelaskan, ada banyak ibu yang mengira susu merek tertentu adalah produk impor. Ternyata dugaan tersebut tidak benar karena merek tersebut diproduksi di Indonesia. Mengingat karakter orang Indonesia yang cenderung berorientasi pada merek, maka bisa dipahami jika merek akan berpengaruih secara signifikan pada niat beli.

Menjadi cukup mengejutkan adalah country-of-origin yang ternyata tidak memberikan pengaruh yang signifikan pada niat beli produk susu import. Fenomena ini mungkin terjadi karena konsumen bahkan tidak tahu di 
negara mana produk susu yang mereka beli tersebut dihasilkan. Informasi tentang lokasi produksi ternyata tidak cukupp menarik dalam pengambilan keputusan pembelian produk susu import.

\subsection{Uji beda Variabel Country-of-Origin}

Dalam penelitian ini, anova digunakan untuk melihat apakah ada perbedaan variabel country-of-origin berdasarkan kelompok usia responden dan tingkat pengeluaran keluarga. Selain itu juga digunakan untuk melihat apakah ada perbedaan niat beli berdasarkan tingkat pengeluaran keluarga responden.

\subsubsection{Uji Beda Variabel Country-Of-Origin Berdasarkan Usia}

Pengelompokan berdasarkan usia responden dilakukan untuk analisis uji beda variabel ini. Langkah pertama adalah mencari nilai rata-rata dan kemudian dilakukan uji beda dengan anova.

Tabel 5.

Mean Variabel Country-Of-Origin Berdasarkan Usia

\begin{tabular}{ccc}
\hline & $\mathbf{N}$ & Mean \\
\hline$<=20$ tahun & 3 & 4.400 \\
21-30 tahun & 81 & 4.005 \\
30-40 tahun & 87 & 4.421 \\
$>40$ tahun & 41 & 4.673 \\
Total & 212 & 4.310 \\
\hline Sumber $:$ hasil estimasi mean variabel
\end{tabular}

Terlihat dari tabel diatas rata-rata variabel country-of-origin berdasarkan usia responden. Dilihat dari mean data tersebut diketahui bahwa rata-rata variabel country-of-origin untuk kelompok usia diatas 40 tahun paling besar. Ini menunjukkan bahwa kelompok ini mempunyai kecenderungan orientasi pada country-of-origin paling tinggi. Dimungkinkan kelompok ini mempunyai informasi yang lebih banyak mengenai negara produsen atau bisa juga kelompok ini diasumsikan mempunyai tingkat perekonomian keluarga yang cukup mapan sehingga mereka terobsesi dengan produk import. Kelompok usia 20-30 tahun mempunyai mean yang paling rendah. Hal ini diduga karena kelompok ini adalah mereka yang baru saja membentuk keluarga sehingga informasi tentang negara produsen tidak terlalu tinggi. Data tersebut akan dianalisis apakah nilai rata-rata masing-masing kelompok usia berbeda secara signifikan atau tidak. Berikut adalah hasil uji beda dengan menggunakan anova.

Tabel 6.

Uji Beda Variabel Country-Of-Origin Berdasarkan Usia

\begin{tabular}{llccccc}
\hline & Sum of Squares & df & Mean Square & F & Sig. \\
\hline COO & & & & & \\
& Between Groups & 14.036 & 3 & 4.679 & 8.176 & .000 \\
& Within Groups & 119.021 & 208 & .572 & & \\
& Total & 133.057 & 211 & & & \\
\hline
\end{tabular}

Sumber : hasil estimasi uji beda

Dengan menggunakan alat bantu SPSS 10,0 diketahui bahwa probabilitas sebesar 0,00. Karena probabilitas $<0,05$ maka Ho ditolak. Hal ini berarti ada perbedaan yang signifikan antar kelompok usia responden terhadap variabel country-of origin. 


\subsubsection{Uji Beda Variabel Country-Of-Origin Berdasarkan Tingkat Pengeluaran Keluarga}

Langkah yang sama juga dilakukan untuk menguji perbedaan penilaian terhadap country-of-origin pada kelompok-kelompok yang mempunyai tingkat pengeluaran keluarga yang berbeda. Tabel 4.6. menunjukkan nilai rata-rata penilaian terhadap country-of-origin pada kelompok yang mempunyai tingkat pengeluaran keluarga yang berbeda.

Tabel 7.

Mean Variabel Country-Of-Origin

Berdasarkan Tingkat Pengeluaran Keluarga

\begin{tabular}{ccc}
\hline & N & Mean \\
\hline < Rp 2.000.000 & 24 & 3.308 \\
Rp. 2 juta - Rp 4 juta & 125 & 4.259 \\
$>$ Rp 4.000.000 & 63 & 4.794 \\
Total & 212 & 4.310 \\
\hline
\end{tabular}

Sumber : hasil estimasi mean variabel

Terlihat dari tabel diatas rata-rata variabel country of origin berdasarkan tingkat pengeluaran keluarga. Dilihat dari mean data tersebut diketahui bahwa rata-rata variabel country-of-origin untuk kelompok responden dengan tingkat pengeluaran keluarga lebih dari Rp. 4.000.000,-paling besar. Ini menunjukkan bahwa kelompok ini mempunyai kecenderungan orientasi pada country-of-origin paling tinggi. Dimungkinkan kelompok ini mempunyai informasi yang lebih banyak mengenai negara produsen. Penjelasan lain adalah semakin tinggi tingkat pengeluaran keluarga - yang mungkin berkorelasi positif dengan tingkat pendapatan keluarga - akan semakin mendorong seseorang untuk membeli produk yang mereka persepsikan sebagai produk yang brekualitas tinggi. Dan salah satu parameternya adalah produk yang berasal dari negara maju (baca: western). Sehingga kelompok ini akan membeli produk yang mereka citrakan berasosiasi dengan negara maju.

Nilai rata-rata masing-masing kelompok trersebut akan diuji beda dengan menggunakan anova. Berikut adalah hasil olah data tersebut.

Tabel 8.

Uji Beda Variabel Country-Of-Origin Berdasarkan Tingkat Pengeluaran Keluarga

\begin{tabular}{llllll}
\hline & Sum of Squares & df & Mean Square & F & Sig. \\
\hline COO Between Groups & 39.139 & 2 & 19.570 & 43.550 & .000 \\
Within Groups & 93.918 & 209 & .449 & & \\
Total & 133.057 & 211 & & & \\
\hline
\end{tabular}

Sumber : hasil estimasi uji beda

Dengan menggunakan alat bantu SPSS 10,0 diketahui bahwa probabilitas sebesar 0,00. Karena probabilitas $<0,05$ maka Ho ditolak. Hal ini berarti ada perbedaan yang signifikan antar tingkat pengeluaran keluarga terhadap variabel country-of origin.

\subsection{Uji Beda Variabel Niat Beli Berdasarkan Tingkat Pengeluaran Keluarga}

Pengelompokan berdasarkan tingkat pengeluaran keluarga dilakukan untuk analisis uji beda penilain masing-masing kelompok terhadap variabel niat beli. Langkah pertama adalah mencari nilai rata-rata dan kemudian dilakukan uji beda dengan anova. 
Tabel 9.

Mean Variabel Niat Beli Berdasarkan Tingkat Pengeluaran Keluarga

\begin{tabular}{ccc}
\hline & N & Mean \\
\hline$<$ Rp 2.000.000 & 24 & 2.563 \\
Rp. 2 juta - Rp 4 juta & 125 & 3.540 \\
$>$ Rp 4.000.000 & 63 & 4.274 \\
Total & 212 & 3.647 \\
\hline
\end{tabular}

Sumber : hasil estimasi mean variabel

Terlihat dari tabel diatas rata-rata variabel niat beli berdasarkan tingkat pengeluaran keluarga. Dilihat dari mean data tersebut diketahui bahwa rata-rata variabel niat beli untuk kelompok responden dengan tingkat pengeluaran keluarga lebih dari Rp. 4.000.000,- paling besar. Rata-rata niat beli semakin menurun seiring dengan menurunnya tingkat pengeluaran keluarga. Ini menunjukkan bahwa semakin tinggi pengeluaran seseorang - yang kemungkinan berkorelasi positif - dengan tingkat pendapat, akan mendorong orang untuk semakin berniat membeli produk susu import. Fenomena ini sangat sesuai dengan realita bahwa susu import memang lebih mahal dari pada susu buatan dalam negri.

Nilai rata-rata masing-masing kelompok trersebut akan diuji beda dengân menggunakan anova. Berikut adalah hasil olah data tersebut.

Tabel 10.

Uji Beda Variabel Niat Beli Berdasarkan Tingkat Pengeluaran Keluarga

\begin{tabular}{llccccc}
\hline & & Sum of Squares & df & Mean Square & F & Sig. \\
\hline NIAT & Between Groups & 54.411 & 2 & 27.205 & 53.303 & .000 \\
& Within Groups & 106.671 & 209 & .510 & & \\
Total & 161.081 & 211 & & & \\
\hline
\end{tabular}

Sumber : hasil estimasi uji beda

Dengan menggunakan alat bantu SPSS 10,0 diketahui bahwa probabilitas sebesar 0,00. Karena probabilitas $<0,05$ maka Ho ditolak. Hal ini berarti ada perbedaan yang signifikan antar tingkat pengeluaran keluarga terhadap niat beli susu import.

\section{PENUTUP}

Dengan metode analisis regresi, diketahui bahwa variabel harga dan merek mempunyai pengaruh yang signifikan pada variabel niat beli produk susu import pada tingkat signifikansi $5 \%$. Sedangkan variabel country-oforigin ternyata tidak memberikan pengaruh yang signifikan pada terbentuknya niat beli konsumen pada produk susu import. Dengan temuan ini maka, importir produk susu di pasar Indonesia perlu mengkaji ulang strategi import mereka. Mengingat mahalnya biaya import, perlu dipertimbangkan untuk melakukan aktivitas produksi di dalam negri. Terlebih lagi, terbukti dalam penelitian ini, lokasi (negara) produsen tidak memberikan pengaruh yang signifikan pada keputusan pembelian produk susu. Variabel harga memberikan pengaruh yang paling besar terhadap variabel niat beli produk susu import. Hal ini bisa dijelaskan dengan fenomena sensitivitas pada harga. Dari analisis ANOVA diketahui bahwa ada perbedaan penilaian variabel country-of-origin berdasarkan kelompok usia responden. Kelompok usia diatas 40 tahun mempunyai rata-rata yang paling besar. Dengan alat yang sama ditemukan bahwa ada perbedaan penilaian variabel country-of-origin berdasarkan tingkat pengeluaran keluarga. Kelompok responden dengan tingkat pengeluaran diatas Rp. 4.000.000,- mempunyai rata-rata yang paling besar. Terlihat juga bahwa semakin tinggi tingkat pengeluaran keluarga, maka semakin tinggi pula penilaian responden mengenai variabel country-of-origin. 
Selain itu dalam penelitian ini juga diperoleh masukan bahwa ada perbedaan niat beli produk susu import berdasarkan tingkat pengeluaran keluarga. Kelompok responden dengan tingkat pengeluaran diatas Rp. 4.000 .000 ,- mempunyai rata-rata yang paling besar. Terlihat juga bahwa semakin tinggi tingkat pengeluaran keluarga, maka semakin tinggi pula niat beli konsumen akan produk susu import.

\section{DAFTAR PUSTAKA}

Aaker, David A(1997), Manajemen Ekuitas Merek: Menafaatkan Nilai dari Suatu Merek, terjemahan, Penerbit Mitra Utama

Ahmed, Zafar U, James P Johnson dan Lim Chee Boon (2004), Does Country of Origin Mater for Low-Involvement Products?, International Marketing Review, Vol. 12, No. 1, pp. 102-120

Badri, Masood A, Donald L Davis, dan Donna F Davis (1995), Decision Support for Global Marketing Strategies: The effect of Country-of-Origin on Product Evaluation, Journal of Product and Brand Management, Vol. 4, No. 5, pp.49-64

Czinkota, Michael R, dan Ilkka A Ronkainen (2001), International Marketing, Sixth edition, Florida: Harcout

Etteson, R, G Gaeth (1988), "Commentary: Consumers' Perception on Hybrid bi-national Products", Journal of Cosumer Marketing, Vol/ 8. No. 4, pp. 13-18

Kaynak, Erdener dan Ali Kara (2002), "Consumer Perceptions Of Foreign Products: An Analysis Of ProductCountry Images And Ethnocentrism", European Journal of Marketing, Vol. 36, Issue 7/8

Kaynak, Erdener, Orsay Kucukemiroglu, dan Akmal S Hyder, (2000), "Consumers' COO Perceptions Of Imported Products In A Homogenous Less-Developed Country", European Journal of Marketing, Vol. 34, Issue $9 / 10$

Kotler, Philip (2003), Marketing Management, Eleventh Edition, New Jersey: Prentice Hal, Inc.

Kotler, Philip., Gary Amstrong (2004), Principles of Marketing, Tenth Edition, New Jersey: Prentice Hal, Inc.

Lin, Chien Huang., dan Dany T Kao (2004), "The Impacts of Country-of-Origin on Brand Equity", The Journal of American Academy of Business, Cambridge, September

Roth, MS, JB Romeo (1992), "Matching Product and Country Image Percepstions: A Framework for Managing Country-of-origin Effects", Journal of International Business Studies, Vol. 23, No. 3, pp. 477-497

Schiffman, Leon G. dan Leslie Kanuk (2000), Consumer Behavior, Fifth Edition, New Jersey: Prentice Hal, Inc.

Sekaran, Uma (1992), Research Method for Business: A Skill Building Approach, Second Edition, Singapore: John Wiley \& Sons, Inc.

Zhang, Yong (1996), "Chinese Consumers' Evaluation of Foreign Products: The Influence of Culture, Product Types, and Product Presentation Format", European Journal of Marketing, Vol. 30, Issue 12, pg. 50 